\title{
Dependency: an inhibitor to the Irish case for corporate social responsibility

\author{
Ciara Hackett ${ }^{1}$
} \\ Queen's University Belfast
}

\begin{abstract}
$\underline{\text { Abstract }}$
This paper addresses the potential resurgence of the post-imperial "dependency theory" of the 1960s and 1970s. Suggesting that the initial premise of the theory was just, the article proposes the reworking of the theory in order to incorporate globalisation processes, namely the importance of global capital generated by multi national corporations. Considering that capital is now at the "core", leads to the idea of a much wider catchment of states "dependent" on global capital. Using Ireland as an example, this article pursues the idea that a dependent state's ability to implement corporate social responsibility legislation is inbibited by the constraints of capital.
\end{abstract}

\section{Introduction}

$\mathrm{D}$ ependency theory was briefly fashionable in the 1960s and 1970s as an alternative theory of development. Problems associated with the theory, such as its failure to provide a solution for "dependence", have meant that it lost its prominence in recent times. This paper applies a modified dependency theory - a "new" dependency - in an effort to provide an alternative assessment of the global order and to question the power of the nation state to control or regulate transnational capital. This paper focuses on Ireland, a relatively wealthy state, which falls within new dependency. Dependence is reflected in the failure of the Irish government to act independently on issues pertaining to regulation which therefore means that the Irish government cannot influence an effective corporate social responsibility (CSR) policy for Ireland due to its dependence on foreign capital. CSR is the deliberate inclusion of public interest into decision making within corporations in a manner which befits the "triple bottom line" approach to business self-regulation - people, planet and profits. Or, perhaps on a wider interpretation, CSR includes the broader regulatory framework, a set of mechanisms for aligning corporate behaviour with the

1 PhD student at Queen's University Belfast. Email: chackett04@qub.ac.uk or ciarahackett@hotmail.com. 
interests of society in reducing externalities and promoting a sustainable corporate sector. ${ }^{2}$ The first section addresses traditional dependency. Then, the article goes on, in the second section, to consider the emergence of "new" dependence - that of dependence on foreign capital generated by multi-national corporations (MNCs). In the third section, Ireland is discussed, reflecting on past examples of how dependence on capital has influenced government decisions and policy. The final part considers the unlikelihood of a mandatory CSR policy in Ireland as a result of said dependence.

\section{Dependency theory}

Dependence is best described by Dos Santos as "a conditioning situation in which the economies of one group of countries are conditioned by the development and expansion of others". ${ }^{3}$ Relationships of dependence exist:

when some countries can expand through self impulsion, while others being in a dependent position, can only expand as a reflection of the expansion of the dominant countries, which may have positive or negative effects on their immediate development. ${ }^{4}$

Therefore, a dependent state is one where economic development, policies and, to a certain extent, social policy are dependent on the input, investment and interest of others. ${ }^{5}$

Dependency theory emerged following the failure of Keynesian economics in accounting for the effects of imperialism on social structures and patterns of economic development in countries of the Third World ${ }^{6}$ and as a reaction against neoclassical theories of development, such as modernisation. ${ }^{7}$ Dependency theorists criticised modernisation for ignoring the historical nuances particular to the country which, they believed, cemented its underdevelopment. ${ }^{8}$

A number of key beliefs exist in dependency literature. Dependency advocates a centre of wealthy "developed" states relying on the appropriation of profit from a periphery of

2 J Elkington, Cannibals with Forks: The triple bottom line of 21st century business (Oxford: Capstone 1998). For an indepth history of CSR evolution, please refer to: C Vurro, "The evolutionary path of the concept of CSR" in F Perrini, S Pogutz and A Tencati (eds), Developing CSR (Cheltenham: Edward Elgar Publishing 2006), p. 54; AB Carroll, "Corporate social responsibility - evolution of a definitional construct" (1999) 38(3) Business and Society 268; SF Deakin and R Hobbs, "False dawn for CSR? Shifts in regulatory policy and the regulatory policy response of the corporate and financial sectors in Britain" (2007) 15(1) Corporate Governance: An international review 68-76, available at SSRN: http://ssrn.com/abstract=954817 or DOI: $10.1111 /$ j.1467-8683.2007. 00543.x.

3 T Dos Santos, "The crisis of development theory and the problem of dependence in Latin America" in H Bernstein (ed.), Underdevelopment and Development (Harmondsworth: Penguin 1973).

4 Ibid.

5 Dependency traditionally operated on the premise that there exists a core of wealthy "developed" states and a periphery or satellite of poorer "underdeveloped" states. In order to bolster economic growth in the core, resources were extracted from the periphery to sustain growth in the centre. It suggests that peripheral regions were exploited to a certain extent by the core so as to sustain core development. When addressing new dependency in the next section, I suggest that all nation states today are peripheral to the "core" of transnational capital.

6 I Roxborough, Theories of Underdevelopment (London: Macmillan 1979).

7 Modernisation theory believed that capital invested in a nation (through technological advances) could develop a nation socially and economically. It became the way in which the USA addressed the transformation of the colonies of Britain and France and how they could survive on the world market.

8 AG Frank, "The underdevelopment of development" (1991) 10(3) Scandinavian Journal of Development Alternatives 133-50. 
poorer "underdeveloped" states in order to increase the centre states' capital accumulation. ${ }^{9}$ There is a focus on historical aspects of "development" and/or "underdevelopment"10 with theorists arguing for the interrelation of economic, political and social aspects within a development theory. ${ }^{11}$

Criticism of dependency focuses on the failure to provide expert knowledge of Marxist theories - particularly exploitation; ${ }^{12}$ concrete typologies of "cores" and "peripheries"; $; 3$ a solution to dependence; ${ }^{14}$ and its existence as a critique of modernisation. ${ }^{15}$ To these, I add a further criticism: that dependency is concerned with the nation state and instances of dependence between individual states. Given the systematic shift towards globalisation, it is no longer viable to consider only nation state transactions. The next section of this paper suggests the need to consider dependency on a transnational level and, particularly, dependence on foreign capital generated through the MNC, as well as the impact of globalisation and the rise of the transnational capitalist class (TCC).

\section{New dependency}

Given the criticisms outlined above, how ought we to imagine dependency? In this section, I set out a conception of dependency rooted in the patterns of capitalist globalisation that have emerged since traditional dependency theory's heyday.

New dependency suggests that peripheral countries are no longer dependent on core countries for economic growth. Instead, it suggests that transnational capital is the "core" with the majority of nation states being considered "peripheral" in the extent to which they depend on foreign capital through MNC investment for "wealth". ${ }^{16}$ By reclassifying dependency in this way, I address criticisms of the theory ${ }^{17}$ as well as incorporating developments such as increasing globalisation and the dominance of the TCC. ${ }^{18}$

9 R Prebisch, The Economic Development of Latin America and its Principal Problems (New York: United Nations 1950); AG Frank, "Sociology of underdevelopment and underdevelopment of sociology" (1967) 3 Catalyst 20-73.

10 Frank, "The underdevelopment of development", n. 8 above.

11 Frank, "Sociology of underdevelopment", n. 9 above.

12 G Kay, Development and Underdevelopment: A Marxist analysis (London: Macmillan 1975).

13 C Leys, "Underdevelopment and dependency: critical notes" (1977) 7(1) Journal of Contemporary Asia 92-107; D Booth and AG Frank, "An introduction and an appreciation" in I Oxaal, T Barnett and D Booth (eds), Beyond the Sociology of Development (London: Routledge \& Kegan Paul 1975).

14 D Booth, "Marxism and development: sociology interpreting the impasse" (1985) 13(7) World Development 76-87; J Toye, Dilemmas of Development: Reflections on the counter revolution in development economics $2 \mathrm{nd}$ edn (Oxford: Blackwell 1993); F Schurmann, Beyond the Impasse: New directions in development theory (London: Zed Books 1993). I don't believe that the failure to provide a solution is a major issue. It is sufficient that the theory can be used as a means of describing certain phenomena. For example, it is enough to apply to the theory to a country or region and thereby provide an alternative unit of analysis in an assessment of that region's development. Ireland's development and economic advancement is generally measured using traditional economic theory. However, by a re-reading of Ireland's success through the lens of dependency, previous "successes" can be reappraised.

15 Leys, "Underdevelopment and dependency", n. 13 above; A Cueva, "Crisis del capitalismo y perspectivas del nacionalismo en América Latina (análisis del caso ecuatoriano)” (1976) 38(4) Revista Mexicana de Sociología 825-41, cited in RH Chilcote, "A question of dependency" (1978) 13(2) Latin American Research Review 55-68.

16 Issues of exploitation of the periphery by the core manifest in peripheral approaches to regulation etc. as considered in the next section.

17 Leys, "Underdevelopment and dependency", n. 13 above; Booth and Frank, "An introduction and an appreciation", n. 13 above.

18 L Sklair, Transnational Capitalist Class (Oxford: Blackwell 2001). 
The relationship between dependency and the MNC has been discussed before. ${ }^{19}$ The difference with new dependency, however, is that whereas traditional dependency suggested that the MNC was a powerful agent of a core country ${ }^{20}$ - usually the USA - new dependency suggests that the MNC is the core or at least an agent of the TCC. ${ }^{21}$

This approach provides an alternative assessment of the situation in small, open, globalised economies today, like Ireland. The role of MNCs and the corresponding TCC questions some issues of governance. How can the borderless MNC, and in turn global capital, be regulated by an - inferior by comparison - domestic state which is dependent on global capital for prosperity? This is the dilemma which globalisation, viewed via dependency, poses. Global capital's answer to this dilemma are methods of self-regulation, such as CSR, as means of regulating companies, whilst ensuring return to the people in the countries where they are based. As ensuing sections illustrate, dependence on foreign capital makes it unlikely that nation states will be able to influence the direction of said CSR policies in ways best fitting their specific requirements.

Ireland, prior to the Celtic Tiger era, fulfilled all conditions of traditional dependence, with a 1988 Economist article identifying Ireland as having all the hallmarks of a dependent state; the colonial past, the weak industrial sector, the peasant class and the peripheral nation status. $^{22}$ In addition, much literature exists describing the incidence of this dependence. ${ }^{23}$ However, with the coming of the Celtic Tiger, Ireland went from a despondent, stagnant economy to "Europe's shining light", 24 at least while it lasted. Is it the case that modernisation methods of capital infusion ${ }^{25}$ worked for Ireland? Modernisation methods of capital infusion did not work for Ireland. The boom that was the Celtic Tiger is over. ${ }^{26}$ Of note for this paper is the fact that, even when the economy was performing in Ireland's favour, it was still at the mercy of global capital and was, therefore, severely affected by global downturns, as the recent liquidity crisis has illustrated. ${ }^{27}$ Has the Irish case, then, provided a solution to dependency, or has dependency today merely adapted to globalisation and, in doing so, manifested itself accordingly? The latter is the case - as the global economy has developed, so too have the theories used to describe it. This

19 R Müller, "The multinational corporation and the underdevelopment of the Third World" in CK Wilber (ed.), The Political Economy of Development and Underdevelopment (New York: Random House 1973), pp. 124-51; T Biersteker, Multinationals, the State and the Control of the Nigerian Economy (Princeton NJ: Princeton UP 1987); RW Jackman, "Dependence on foreign investment and economic growth in the Third World" (1987) 34(2) World Politics 175-96.

20 PJ O’Brien, "A critique of Latin American theories of dependence" in Oxaal et al., n. 13 above.

21 Sklair, Transnational Capitalist Class, n. 18 above.

22 F Cairncross, "Poorest of the rich", The Economist, 16 January 1988, p. 3.

23 JK Jacobsen, Chasing Progress in the Irish Republic - Ideology, democracy and dependent development (Cambridge: Cambridge UP 1994); L Gibbons, "Coming out of hibernation? The myth of modernity in Irish culture" in R Kearney (ed.), Across the Frontiers: Ireland in the 1990s (Dublin: Wolfhound Press 1988); R Crotty, Ireland in Crisis - A study in capitalist colonial undevelopment (Dublin: Brandon Press 1986); P Breathnach, "Uneven development and capitalist peripheralisation: the case of Ireland" (1988) 20(2) Antipode 122-41.

24 “The Celtic Tiger: Europe's shining light", The Economist, 17 June 1997.

25 H Bernstein, "Modernization theory and the sociological study of development" (1971) 7(2) Journal of Development Studies 141-60; JS Valenzuela and A Valenzuela, "Modernization and dependency: alternative perspectives in the study of Latin American underdevelopment" (1978) 10(4) Comparative Politics 535-57.

26 M Cassidy and D O’Brien, "Export performance and competitiveness of the Irish economy" (2005) 3 Central Bank of Ireland Quarterly Bulletin 75-95; see also M Kelly, "The Irish property bubble: causes and consequences" (paper presented at Irish Economy Conference, Dublin, January 2009).

27 Ireland's boom lasted from around 1995-2002 and was fuelled by the growth of the dot.com industry. Its collapse signified the beginning of the end for the Irish success story and serves to emphasise the level of dependence on foreign capital in the Irish economy. 
incorporates dependence, which, rather than being removed by global change, has become more ingrained.

Globalisation enabled Ireland to move from the periphery towards the centre of the new global economy. ${ }^{28}$ Murphy describes how "a predominately pre-industrialised economy" like Ireland, managed to "leapfro[g] to a post industrial high tech economy" in a very short space of time. ${ }^{29} \mathrm{He}$ suggests that the absence of an industrial sector was beneficial to Ireland, initially, as, it allowed the government to introduce a significant number of tax breaks which would have been difficult, if not impossible, had there been a large industrial base. This in turn attracted companies from Silicon Valley to use Ireland as a European base for their production. ${ }^{30}$ Part attracted by fiscal and tax breaks and the activities of the Industrial Development Authority, ${ }^{31}$ as well as the benefits of an Englishspeaking workforce and geographical benefits around time zones, MNCs began to set up bases in and around the east and south-west of the island, providing indirect and direct employment to the Irish people. ${ }^{32}$

Deeper integration with Europe also aided Ireland's transformation from a stagnant economy to a vibrant cosmopolitan trading region. Ireland, with its full commitment to Europe, and the only English-speaking nation fully committed to European monetary union, was "ideally positioned to act as the pontoon linking US companies to the EU".33 Ireland was indeed in the right place at the right time and, under traditional measures of economic growth, benefited enormously as a result from MNCs, in their attempts to have a foothold in Europe.

But, Ireland is still dependent. Despite the fact that the limited indigenous industrial sector facilitated MNC investment on such a large scale, it is the absence of said sector which highlights Irish dependence. ${ }^{34}$ Therefore, those conditions which helped attract investment are the very conditions which secure Irish dependence. This in turn leaves Ireland

28 AE Murphy, The "Celtic Tiger": An analysis of Ireland's economic growth performance RSC No 2000/16 EUI Working Paper (San Dominico de Fiesole: Robert Schuman Centre for Advanced Studies 2000).

29 Ibid.

30 Ibid., p. 15, particularly high-tech industries such as computers, computer software, pharmaceuticals and chemicals. MNCs are beginning to relocate elsewhere, e.g. Q Fortell and J Scheck, "Dell moving its Irish operations to Poland" (2009) Wall Street Journal, available at http://online.wsj.com/article/ SB123141025524864021.html (visited 30 June 2009).

31 KP Thomas, "Investment incentives; growing use, uncertain benefits, uneven controls" (2007), available at www.globalsubsidies.org/files/assets/GSI_Investment_Incentives.pdf (visited 1 July 2009). In the late 1950s, Ireland's economic development strategy revolved around attracting foreign MNCs, the main attraction being export sales relief (ESR) which exempted all export profits from corporation tax. In 1973, the European Commission insisted that ESR be terminated because it was an export subsidy and "state aid law does not permit export subsidies on intra-Community trade" (ibid.). To provide a similar incentive to encourage investment, the European Commission allowed a $10 \%$ manufacturing corporate income tax rate. Therefore, the Competition Directorate, in drawing up its original "Surveys" on state aid in the late 1980s, deemed this tax rate to be part of the "general macroeconomic framework" of the country and not state aid. However, "in 1998 the Commission reversed its position, ruling that not only was the manufacturing tax rate a state aid, it was an 'operating aid' and, as such, had to be terminated. Competition Directorate policy has long deemed operating aid to be far more likely to distort competition than investment aid, and much harder to justify under the provisions of the Treaty of Rome." (ibid.) Corporate tax was increased to $12.5 \%$.

32 Murphy, Celtic Tiger, n. 28 above; H Gorg and F Ruane, "European integration and peripherality: lessons from the Irish experience" (2000) 23(3) The World Economy 405-21.

33 Murphy, Celtic Tiger, n. 28 above.

34 Irish dependence is for the most part attributable to its size and the nature of a small, open economy. However, desires to retain competitiveness means that Ireland is increasingly having to adapt policy to ensure that capital remains, which in turn is further compromising Ireland's ability to alleviate some of the trappings of dependency. 
susceptible to fiscal dumping, transfer pricing ${ }^{35}$ and the need to retain its comparatively low tax rate in order to avoid capital flight. Faced with the prospect of capital flight, the Irish government adheres to MNC-friendly policy decisions at all times. In other words, policy follows from dependency, not from social need and such like. The next section addresses how the case of the director's compliance statement (DCS) illustrates the unlikelihood of a government-influenced CSR policy in Ireland - due to fears of capital flight.

\section{Dependency and regulation}

Focusing on Ireland, and how Ireland falls within "new" dependency, the previous section noted how, in being dependent, Ireland could be constrained in regulating the MNC effectively. I will, in this section, look at one instance of corporate regulation and discuss the implications for CSR. The proposed DCS in Ireland is a good example of the systematic limitations that prevail in the Irish politico-economic landscape. Although not related to CSR, the DCS presents an interesting aside on how Irish dependence is manifest in the inability of the government to legislate freely. It emphasises how Irish dependence on foreign capital leads to compromises in the regulation and governance of said capital. It has become increasingly difficult for the government to legislate and regulate in an uninhibited manner. Instead, fear of business retaliation looms in the face of innovation, preventing the government from initiating measures to expedite a higher degree of independence from foreign capital. This can best be understood by focusing on the government-initiated proposed DCS, By 1999, Ireland was suffering a series of banking scandals. ${ }^{36}$ Lack of effective regulation and enforcement meant that those "tempted to make serious breaches of company law ha[d] little reason to fear detection or prosecution". 37

The DCS arose from a specific recommendation of the Review Group on Auditing, ${ }^{38}$ requiring directors of major companies to make public statements of compliance with respect to their tax, company law and any other relevant enactments that could affect the company's financial statements which in turn would be assessed by a group of auditors. ${ }^{39}$ The DCS marked a change in direction for Irish regulation as, under the Anglo system of governance, regulation in Ireland was limited. Despite Irish attempts to innovate, however, the ensuing paragraphs show how capital prevented this innovation.

Business reaction to s. 45 was predictable. Senior figures at the International Financial Services Centre said that "Ireland may lose out on future foreign investment if the government does not water down plans to make directors personally responsible for

35 Transfer pricing is the pricing of contributions transferred within an organisation to areas of the organisation where gains can be most profitable. Ireland has a very low tax regime. Therefore, corporations with bases in Ireland may use "creative accounting" procedures in order to attribute more profits to Ireland than was actually the case.

36 D Knights and M O’Leary, "Reflecting on corporate scandals: the failure of ethical leadership" (2005) 14(4) Business Ethics: A European review 359-66; P Appleby, "Corporate regulation in Ireland" in J O’Brien, (ed.), Governing the Corporation: Regulation and corporate governance in an age of scandal and global markets (Dublin: $\mathrm{J}$ Wiley $\&$ Sons 2005). This ranged from issues regarding improper conduct between government officials and the banking community, banks overcharging customers on foreign exchange transactions and the use of bogus non-resident accounts in order to reap tax benefits for a few of a bank's customers.

37 J Suiter, "Compliance rules could hit foreign investment", The Times, 2000.

38 Review Group on Auditing. The Report of the Review Group on Auditing (Dublin: Stationery Office 2000).

39 Appleby, "Corporate regulation in Ireland", n. 36 above. Proposals for DCSs were contained in s. 45 of the Companies (Auditing and Accounting) Act 2003 (Act No. 44 of 2003, Tithe an Oireachtais), available at www.oireachtas.ie/viewdoc.asp?fn=/documents/bills28/acts/2003/a4403.pdf (visited 27 February 2009). 
ensuring companies comply with all forthcoming legislation." 40 In the same report, it was suggested that:

the US can afford to lead in this type of legislation but Ireland cannot. We are an acceptor of standards. We should be looking to benchmark what we do rather than going out on a limb.

Another report stated that:

reaction from the business community to the Bill ... has been quite negative ... As breach of the proposed provisions of the Bill, in most instances, will result in an offence being committed, emphasis will shift from one of concern over corporate compliance and personal exposure rather than promoting and developing competitive business. ${ }^{41}$

A Company Law Review Group (CLRG) designed to address the contentious issues of the DCS stated that:

[a] clear majority of the CLRG considered that it was simply not feasible to commence $45 / 2003$ because of the additional unnecessary costs it causes for companies and the negative and disproportionate effect on national competiveness and the likelihood of dysfunctional behaviour that would see companies registering outside of Ireland and so unaccountable to the Irish authorities. ${ }^{42}$

Reversing their decision was necessary if the Irish government was to avoid capital flight. Ireland is faced with the choice of relative prosperity or an impressive regulatory regime. Dependence forbids their co-existence. Ireland's dependence is now so ingrained that compromises in the field of regulation are being made in order to retain capital in the ever-increasing race to the bottom by MNCs: government cannot dictate the direction of compliance. Article X replaced the DCS but:

will no longer require auditors to opine if the DCS is fair and reasonable. Overall, the provision represents in aggregate a reduction in its scope and effect compared with the original DCS. 43

By considering the case of the DCS in Ireland, assumptions can be made with regard to the potential for an effective CSR policy and other regulatory style controls designed to govern capital. These assumptions would suggest that, as per the DCS issue in Ireland, the Irish government does not have the freedom to legislate effectively on issues concerning foreign capital, due to Irish dependence on this capital. They also illustrate how, as opposed to regulating on foreign capital, the Irish government is constrained in its ability to regulate,

40 Suiter, "Compliance rules", n. 37 above.

41 "Dispatch" (2003) EFC, available at www.efc.ie/publications/dispatch/pdfs/efc_dispatch_14.pdf (visited 16 April 2009).

42 CLRG, Report on the DCS (2005), available at: http://www.entemp.ie/publications/ commerce/2005/clrgreport.pdf (visited 12 April 2009); D Nolan, "Revised directors' compliance statements are a step in the right direction", available at: http://www.finance-magazine.com/ display_article.php?i=5997\&pi=222 (visited 11 March 2009). A Lambe. "Directors' compliance statement section 45 - CLRG shows common sense", available at: http://www.accountancyireland.ie/dsp_articles.cfm/ goto/1187/page/Directors_Compliance_Statement_-_Section_45_-CLRG_Shows_Common_Sense.htm (visited 11 March 09).

43 Office of the Director of Corporate Enforcement, Consultation Notice, available at http://www.odce.ie/en/media_consultation_notices_article.asprx? (visited 16 February 2009). Also, see B Conroy, "Revolutionising Irish company law - the proposed new Companies Consolidation and Reform Act" in A O’Neil and R Keane (eds), Corporate Governance: An Irish perspective (Dublin: Roundhall 2009) who looks at how the proposed watered-down Article X has even further been compromised in order to apply to even fewer companies. 
and, indeed, may be more inclined to compromise on regulatory authority in order to ensure the retention of capital. This in turn suggests that for dependent countries like Ireland, CSR will be limited to the design of the MNC as forcibly to regulate in the area of CSR could have the same effect as the DCS example above illustrates. The next section will consider this in depth and, in doing so, pose the premise that, countries as dependent on foreign capital as Ireland are unlikely ever to enforce a mandatory CSR policy.

\section{What are the implications of dependence on CSR?}

Ireland, along with the UK, is an advocate of the Business in the Community (BitC) approach to CSR. Whereas the UK complements this model with the centralisation of CSR, a minister for CSR and discretionary legislation, Ireland does not. ${ }^{44}$ This section aims to discuss the reasons for this, believing that Irish dependence on foreign capital means that innovation is limited to the retention of capital as opposed to fostering social development beyond the requirements of legislation. Furthermore, evidence from the DCS suggests that facing the prospect of capital relocation, the Irish government will back down rather than lose capital. The section will consider whether the Irish government can ever implement CSR legislation under the current status quo. It acknowledges the system that is in place the $\mathrm{BitC}$ model - and questions whether or not this meets the needs and requirements of an Irish approach to CSR.

Ireland's dependence indicates that Ireland cannot systematically implement CSR legislation. The manner in which the Irish government, in the past, has attempted to legislate upon business regulation, for example, the DCS, illustrates the systematic failures of the Irish case. ${ }^{45}$ The response to the introduction of the DCS exemplifies how dependence on capital can prevent positive development, such as CSR legislation, for Irish communities. The government's volte-face, which has called into question its ability not only to regulate the corporation, but also to shape MNC modes of self-regulation via CSR policy (which could help alleviate some of the implications of dependency), has been the legacy of the DCS. What this case has illustrated is not that the Irish government does not want to innovate, but that it systematically can't. Ireland's innovation is limited to the design of MNCs operating in Ireland. Irish concerns are limited to strategically "keeping" capital without exposing said capital to other requirements, intense regulation and so on. The systematic nature of Irish dependence is so severe that the government cannot dictate the direction of compliance.

Will the government always back down in the face of adversity from the business community? It seems yes, as, for the government, there is no alternative. The governance structure in Ireland could theoretically become significantly weaker and looser in the coming years, as the government attempts to retain its tenuous hold over foreign investment to the detriment of other sections of the community.

Can CSR be promoted in Ireland if dependence inhibits CSR legislation? The beginning of this section stated how Ireland, along with the UK, is an advocate of the BitC model. The concept of $\mathrm{BitC}$ refers to the way governments and societies understand the role of enterprise in society with regard to the resolution of social challenges and the part played by business in community development. ${ }^{46}$ Lozano et al. acknowledge nine key elements of

44 JM Lozano, L Albareda, and T Ysa, Governments and Corporate Social Responsibility (Basingstoke: Palgrave Macmillan 2008).

45 The DCS illustrates systematic failures in Ireland. If Ireland is unable to regulate on issues pertaining to governance, it can be assumed therefore that it will be unable to instigate procedures for mandatory CSR policy.

46 Lozano et al., Governments and Corporate Social Responsibility, n. 44 above. 
this model ranging from the use of CSR to solve the problems of social governance to support for social action initiatives by enterprise through employee volunteering and secondment of staff. 47

Of significant relevance to this paper is the fact that BitC allows for the "voluntary" approach to CSR. However, as recent advances in the UK system illustrate, the UK government is moulding the BitC model and supplementing it with advances in soft and more direct legislation together with the establishment of a ministerial office for CSR. ${ }^{48}$ This, in total, is augmenting the benefits of the $\mathrm{BitC}$ system to the point where the UK model is considered to have "comparatively well developed and institutionalised CSR" standards. ${ }^{49}$ However, Ireland has not displayed the same enthusiasm for complementing the pre-existing BitC model with legislation, centralisation of services and the like. Within the Irish model, this organised approach to CSR is absent. In its place is the Department of Enterprise, Trade and Employment which has the lead responsibility for coordinating policy in CSR. ${ }^{50}$ However, it is the Department of Community, Rural and Gaeltacht Affairs which "contributes to the development of CSR in a community and local development context". ${ }$ Furthermore, the Irish government "especially welcomes the voluntary approach" to CSR 52 and, has not "been so active in developing a national CSR framework". 53 This again can be attributed to the systematic failures within the Irish case. Irish dependence has inhibited, or perhaps even prohibited, the potential for CSR legislation.

Is it the case that CSR in Ireland is restricted to the design of those MNCs operating within its borders? The BitC model advocates the corporate community involvement approach to CSR in Ireland. This approach could be potentially ideal for the Irish case, but not without legislation promoting this process. The UK has been more effective in this area. ${ }^{54}$ However, it may be the case that the UK has merely been effective in implementing the infrastructure which supplements CSR - the institutionalisation of CSR in a ministerial capacity, the drive from discretionary regulation toward more direct regulation in the shape of Article 176, etc. ${ }^{55}$ - but that the UK government's designs on CSR are cosmetic. The UK has advanced considerably since the advent of the Bullock Report ${ }^{56}$ culminating today in the ministerial post on CSR and Article 176. Yet, whether or not the UK government's commitment to CSR is cosmetic or a committed attempt to foster CSR within its borders is unclear. In considering the Cadbury Report and, specifically, that " $\mathrm{t}$ ] he country's economy depends on the drive and efficiency of its companies. Thus the effectiveness with which their boards discharge their responsibilities determines Britain's competitive position", we can see how the UK government's approach to CSR within corporate

47 Lozano et al., Governments and Corporate Social Responsibility, n. 44 above.

48 Ibid., pp. 93-114.

49 Ibid.

50 Oifig and Aire Fiontair, Trádála agus Fostaíochta (Department of Enterprise, Trade and Employment), available at www.entemp.ie/ (visited on 2 February 2009).

51 An Roinn Gnóthaí Pobail, Tuaithe agus Gaeltachta (Department of Community, Rural and Gaeltacht Affairs) available at www.pobail.ie/en/CommunityVoluntarySupports/ (visited 2 February 2009).

52 Lozano et al., Governments and Corporate Social Responsibility, n. 44 above.

53 Ibid.

54 J Moon, Government as a Driver of CSR, Research Paper No 20 (Nottingham: ICCSR 2004), ISSN 1479-5124.

55 Article 176, Companies Act 2006.

56 Lord Bullock, Report of the Committee of Inquiry on Industrial Democracy (London: HMSO 1977). See also, Lord Carr, Industrial Democracy: Bullock Report HL Deb, 23 February 1977, vol. 380 cc. 179-355, available at http://hansard.millbanksystems.com/lords/1977/feb/23/industrial-democracy-bullock-report (visited 11 March 2009); and T Conlon, "Industrial democracy and EEC company law: a review of the draft Fifth Directive" (1975) 24 International and Comparative Law Quarterly 348-59. 
governance may be an attempt to accommodate capital whilst retaining competitiveness the price of low regulation. ${ }^{57}$ This has implications for this paper as the UK, a traditional core country (and considered less dependent than small, open, globalised economies like Ireland under new dependence), is still bound by the demands of capital when legislating upon issues such as CSR. Is CSR therefore merely a way to avoid intense regulation of business behaviour which would thwart UK competitiveness globally? ${ }^{58}$ This could be the cost for a low regulation, competitive model of governance. CSR may be nothing more than a concession - a window-dressing exercise hiding the inadequacies of the UK corporate governance regime.

Despite this, the UK has developed legislation in order to supplement the BitC model. Ireland has not. But, if CSR is designed to be of long-term benefit to the corporation as well as the community, why is there not a more committed desire for it in corporations investing in Ireland? Why is it reliant on goodwill from business as opposed to the realisation of the potential benefits of CSR? The business case for CSR is considered by McBarnet who suggests that:

even the very poor of the world add up in aggregate to a significant market, and new markets are being found in meeting needs in developing countries while simultaneously doing profitable business. ${ }^{5}$

Why has this idea of an eye-catching, low-cost intervention as discussed by McBarnet not been realised in Ireland? The answer lies in the concept of the small, open, globalised economy. A small economy is disadvantaged by the manner it attracts capital. Investing in the US or the UK - with a large potential product consumption base - suggests the need to interrelate business with socially responsible acts. Competing for a slice of the larger economy would theoretically instigate a need for embracing local needs and requirements and incorporating these needs and requirements into company policy. The UK, for example, has an estimated population of $61 \mathrm{~m}^{60}$ compared to Ireland's estimated $4 \mathrm{~m} .{ }^{61}$ This difference corresponds to the potential consumer base in each nation. It is understandable that an MNC operating in both the UK and Ireland would hypothetically be more inclined to foster a vibrant CSR policy in the UK due to the potential benefits in brand recognition in accordance with the larger population. Ireland is once again at a disadvantage. What this suggests is that businesses seek to operate in states for different reasons. With small economies like Ireland, short-term profit maximisation could be the main goal due to the small potential consumer base. With larger economies, such as the UK, endeavouring to establish a niche in the market - and in doing so to compete in a much larger potential consumer base - could mean a more committed desire to incorporate community demands within company policy via CSR. Ireland is destined to dependence on capital without gain because the size of the country's consumer base is another potential disadvantage in the prospect of ever emerging as an "equal" with regards CSR policy.

57 Report of the Committee on the Financial Aspects of Corporate Governance (1992), available at www.ecgi.org/codes/documents/cadbury.pdf (visited 11 March 2009).

58 See also S Wheeler, "Ethics in the workplace" (2007) 18 Law Critique 1-28.

59 D McBarnet, "Corporate social responsibility and the law" in D McBarnet, A Voiculescu and T Campbell, (eds), The New Corporate Accountability - Corporate social responsibility and the law (Cambridge: Cambridge UP 2007), pp. 9-59.

60 www.cia.gov/library/publications/the-world-factbook/print/uk.html (visited 11 March 2009).

61 www.cia.gov/library/publications/the-world-factbook/print/ei.html (visited 11 March 2009). 


\section{Conclusions}

Ireland's inability to develop CSR legislation lies not in an unwillingness to engage in CSR practice but is due to the systematic limitations that prevail in its economic landscape. Ireland cannot implement domestic CSR legislation because of dependence on foreign capital and history suggests that, in Ireland, innovation is punished with the threat of capital flight.

In order for states classified as dependent to have any hope of effective domestic CSR policies, legislation is necessary. But the example of Ireland illustrates that domestic legislation is implausible. Fear of capital relocation is always going to outweigh the potential benefits of any mandatory domestic CSR legislation. However, for Ireland, CSR legislation at a supranational level (the European Union) could be the answer. The EU is becoming the "dynamic" and "competitive" trading bloc. ${ }^{62}$ The likelihood of MNC investment ceasing in the event of EU legislation seems unlikely. Ireland could benefit more than most in this scenario as the only English-speaking member of the Eurozone and the implications this has for MNC investment. A mandatory requirement for CSR could then serve to develop Ireland - for example, the indigenous industrial sector - in a way which may help foster long-term development and even alleviate some of the trappings of Irish dependence.

This paper has considered the disadvantage, for Ireland, of the size of its potential consumer base. Estimated at having a population of approximately $4 \mathrm{~m}$, can Ireland realistically compete with nations such as China with an estimated population of $1313 \mathrm{~m},{ }^{63}$ or even the UK at $61 \mathrm{~m}$ ? Probably not. The EU does not have this problem. The potential size of an EU economy would be a more effective bargaining tool with globalised capital. However, as the UK case has shown, all regions are dependent to some extent and it may be that a mandatory CSR policy is simply one step too far and perhaps could compromise EU competitive potential.

In conclusion, there is a possible solution for Ireland with regard to effective CSR policy but the likelihood of its being put into effect is improbable due to the demands of capitalism. Furthermore, any supranational legislative proposal on CSR would have to challenge the voluntary ethos of CSR policy in the European Union. The question becomes whether or not competitiveness or CSR is more important to the development of the EU as a leading trading bloc. For now, it seems as though the desire to be a competitive bloc supersedes designs on CSR.

62 Report of the Presidency Conclusions of the Lisbon European Council 23 and 24 March 2000, available at www.europarl.europa.eu/summits/lis1_en.htm\#b (visited 26 February 2009).

63 www.intercultures.ca/cil-cai/country_overview-en.asp?ISO=CN (visited 11 March 2009). 